\title{
Trial suggests vaccines could aid HIV therapy
}

Erika Check, Washington

A therapeutic vaccine could help patients with HIV to take a break from their exacting drug treatments, according to a prominent immunologist.

Brigitte Autran, a physician at the PitiéSalpêtrière Hospital in Paris, revealed the results of her recent study on 3 April at a Keystone symposium on HIV vaccines in Banff, Canada.

At the very least, Autran claims, the study offers the best evidence yet for the promise of a therapeutic vaccine in managing HIV. But the small size of the clinical trial has led some researchers to question the findings.

"Our results suggest that a vaccine that does not provide sterilizing immunity could still have an impact on the clinical management of the disease," Autran told the meeting. "This is one of the first proofs of principle supporting the concept of therapeutic immunization."

A therapeutic vaccine would not stop people from contracting HIV. But, in theory, it could be used to boost the immune systems of individuals with HIV who are undergoing 'highly active anti-retroviral therapy' (HAART).

Many HIV patients in wealthy countries are now being prescribed HAART in an effort to delay the onset of AIDS. It suppresses HIV but also causes harsh sideeffects, and patients eventually develop resistance to the treatment. Using a therapeutic vaccine to boost the body's immune system in the fight against the virus might allow patients to take a break from HAART. This would provide both a respite from the sideeffects and an extension to the useful lifetime of the therapy.

Autran says that her trial is the first to show that a vaccine can do just that. She and her colleagues injected $48 \mathrm{HIV}$-infected people on HAART with a therapeutic vaccine, which contained HIV genes stitched into a harmless bird virus.

Autran says that more than half of the patients developed immune responses to the vaccine. All of the patients then went off HAART, and doctors measured how long their immune systems could control HIV. Those who developed immune responses to the vaccine managed to stay off HAART for a median of 10 weeks, around 18 days longer than those who did not respond, Autran says. Although she admits that the effect was relatively small, Autran says that it could be amplified with better vaccines.

Other scientists point out that Autran's trial did not include a control group of patients on HAART who did not receive the vaccine, so it is hard to know whether the vaccine actually benefited the patients. Researchers such as Martin Markowitz and his colleagues at the Aaron Diamond AIDS Research Center in New York have also found that patients on HAART can develop strong immune responses to vaccines. But in the long term, this did not allow the patients to stay off HAART any longer than patients who were not vaccinated (M. Markowitz et al. J. Infect. Dis. 186, 634-643;2002).

"Autran's data confirm the fact that the immune system can control the virus to some degree," Markowitz says, "but the challenge is whether we can harness the immune system to control the virus over the long term."

This does not invalidate the therapeutic-vaccine approach, Markowitz adds. Like Autran, he believes that better vaccine candidates could translate into stronger results. Both he and Autran used the best vaccines available for their trials, but newer vaccine candidates might prove to be more effective.

Convincing regulators to approve a therapeutic HIV vaccine may be a challenge in itself, however, as it is unclear what data would be needed to indicate efficacy. Most vaccines work by blocking infection entirely, says Alan Landay, an immunologist at Rush Medical College in Chicago. Landay is

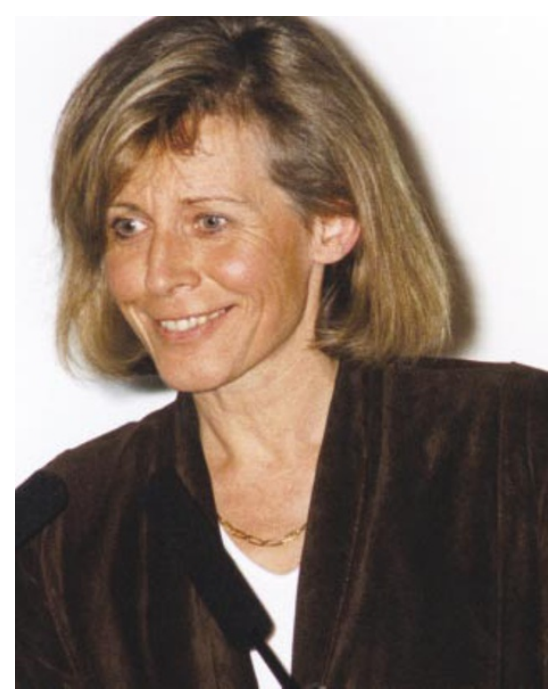

Brigitte Autran thinks the vaccines can augment drug therapies for managing HIV.

organizing a meeting in Washington later this month to bring government officials, industry representatives and scientists together to talk about how best to proceed with therapeutic vaccines.

\section{Chemists' salaries turn south}

\section{Hannah Hoag, Washington}

The wallets of newly qualified US chemists are getting lighter for the first time since the mid-1990s. The American Chemical Society's annual salary survey shows that the median salary for PhDs in 2002 has dropped $\$ 2,000$, to $\$ 67,500$.

Salaries for newly awarded $\mathrm{PhDs}$ have climbed steeply in recent years - they now earn around 50\% more than those who qualified six years ago. But this year's fall in starting salaries suggests that the trend is changing, probably because the economic

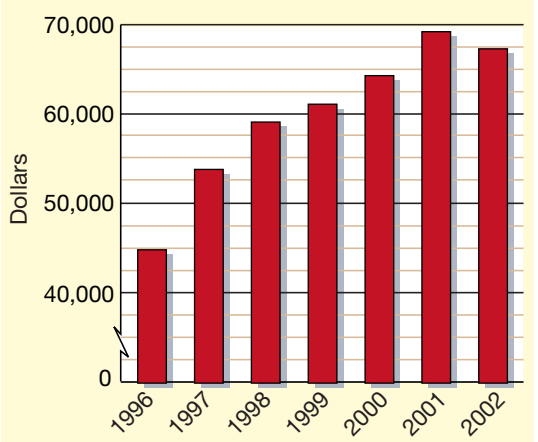

Average starting salaries for chemistry PhDs in the United States take a dip. expansion of the 1990s has come to an end. Median starting salaries of $\$ 71,000$ for $\mathrm{PhDs}$ in industry is one reason that, overall, twice as many chemists are employed in the industrial sector as in research institutions. But large chemical companies such as DuPont and Dow aren't wooing newly qualified chemists any more, says Charles Casey, president-elect of the American Chemical Society. New chemists are more likely to start their careers with smaller companies, he says, a move that could account for the dip in salaries.

Hannah Bernstein, an assistant director of the Careers Office at the Massachusetts Institute of Technology (MIT), says that PhDs from MIT who might have gone on to industry or consulting in the past are now pursuing postdoctoral training. According to the society's survey, $47 \%$ of new masters were opting for further study in 2002, compared with $27 \%$ in 2000 .

Bernstein contends that salaries are lower across all scientific disciplines. During the economic boom, companies had to offer large salaries and signing bonuses to be competitive and attract good candidates, she says, but now they offer less. "The overall economy may be the driver," agrees Casey. 